\title{
DAXX Gene
}

National Cancer Institute

\section{Source}

National Cancer Institute. DAXX Gene. NCI Thesaurus. Code C24330.

This gene plays a role in signal transduction, regulation of transcription and enhancement of apoptosis. 